\title{
РОЛЬ В. Б. АНТОНОВИЧА У ФОРМУВАННІ ТА ПОШИРЕННІ УКРАЇНСЬКОЇ НАЦІОНАЛЬНОЇ ІДЕЇ
}

\author{
О. М. Богдаиина
}

\begin{abstract}
Богдашина О. М. Роль В. Б. Антоновича у формуванні та поширенні української національної ідеї у Російській імперії. У статті розглянуто умови та канали поширення української національної ідеї В. Б. Антоновичем у суспільстві, показано специфіку її трактовки видатним істориком. Особливу увагу приділено ролі професора у сприйнятті його студентами ідей українофільства під час навчального процесу та позаудиторного спілкування та, як наслідок, залучення В. Б. Антоновичем молоді до громадсько-політичної діяльності.
\end{abstract}

Ключові слова: українська національна ідея; Київський університет Св. Володимира; В. Б. Антонович.

Богдашина Е. Н. Роль В. Б. Антоновича в формировании и распространении украинской национальной идеи в Российской империи. В статье рассмотрены условия и каналы распространения украинской национальной идеи В. Б. Антоновичем в обществе, показана специфика ее трактовки выдающимся историком. Особое внимание уделено роли профессора в восприятии его студентами идей украинофильства во время учебного процесса и внеаудиторного общения и как следствие привлечения В. Б. Антоновичем молодежи к общественно-политической деятельности.

Ключевые слова: украинская национальная идея; Киевский университет Св. Владимира; В. Б. Антонович.

Bohdashyna O. The Role of V. B. Antonovich in the Formation and Spreading of the Ukrainian National Idea in the Russian Empire. The article examines the conditions and channels for the spreading of the Ukrainian national idea by V. B. Antonovich in society, and shows the specifics of the treatment by an outstanding historian. Particular attention is paid to the role of the professor in the perception of his students of the ideas of Ukrainophilism during the educational process and non-audience communication and as a consequence of attracting of youth to social and political activity by V. B. Antonovich.

Keywords: Ukrainian national idea; St. Vladimir University in Kiev; V. B. Antonovich.

Одним із лідерів українського руху у другій половині XIX - на початку XX ст. у Російській імперії був В. Б. Антонович. Ще сучасники високо оцінили роль видатного історика у творенні та поширенні української національної ідеї. За оцінкою С. О. Єфремова В. Б. Антонович зміг «глибоко увійти в народне життя, полюбити його і зрозуміти український рух до найглибших основ його» ${ }^{1}$ С. О. Єфремов вважав, що громадська робота для Володимира Боніфатійовича була «потребою духа, як і наукові досліди»². Інший його знайомий - I. Я. Франко зазначав, що «як професор історії, він дав імпульс своїм ученикам до спеціального оброблювання поодиноких територій української землі, і ся його ініціатива принесла досить багаті плоди» ${ }^{3}$. Активний діяч Одеської громади А. С. Синявський вважав, що «в особі В. Б. сходяться нитки громадських зносин. Оборона культурних інтересів, політичні зв'язки, матеріальні можливості об'єднуються в особі В. Б., - визнаного значною суспільністю проводиря українського руху того часу майже на всій території українського народу од Галичини й Закарпаття на заході й Кубані, Ставропілля на сході» ${ }^{4}$.

Радянськими дослідниками українські переконання та активна громадсько-політична діяльність лідера Старої Київської громади оцінювалися здебільшого вкрай негативно як «буржуазний націоналізм». У численних новітніх дослідженнях, присвячених історії українського національного руху та, зокрема, його ідеології, завжди присутня постать лідера українофілів. Проте не усі важливі факти з життя В. Б. Антоновича, пов язані з формуванням та поширенням ученим української національної ідеї дістали належне висвітлення у науковій літературі.

Метою нашої статті є оцінка ролі В. Б. Антоновича у творенні та поширенні української національної ідеї у Російській імперії у другій половині XIX - на початку XX ст. 
Відразу хотілося б зробити ряд застережень. Перше з них стосується термінів. Поняття «Україна» та «український» у XIX ст. менше використовувалося, ніж слова «Малоросія», «малоросійський», «південноруський», які інколи використовуємо переважно у цитатах 3 джерел досліджуваного періоду і ми. Під терміном «українофільство» розуміємо насамперед суспільно-політичний рух та ідеологію 1860-х - 1890-х років, які висували переважно культурно-просвітницькі, а не політичні завдання. Лідер руху В. Б. Антонович називав українофілами «тих уродженців Південно-руського краю, які настільки знайомі 3 своєю батьківщиною, що встигли констатувати відмінні риси іiі народонаселення, настільки розвинуті, що викласти можуть і літературно свої переконання, настільки люблять свою батьківщину і бажають іiі розвитку й успішності, що вважали б справою гріховною замовчувати iiï особливості і потреби, які з цих особливостей випливають, настільки не виключно зациклені на турботі про особисту кар'єру й добробут, що в міру можливості, у законних рамках готові відстоювати свої переконання, незважаючи на пересуди, які зазвичай зустрічають ï думки, і на наслідки цих пересудів» ${ }^{5}$. Цікаво, що М. І. Костомаров подав більш звужену трактовку, бо ототожнював українофільство «з прагненням деяких малоросів писати на своєму рідному наріччі і разом 3 тим вивчати багату скарбницю народної поезії» ${ }^{6}$.

Еволюція української національної ідеї з культурно-просвітницької у державницьку припадає на кінець «довгого» XIX ст. Історик взагалі не пов'язував вирішення українського питання з державною самостійністю українців.

Для характеристики українців як етносу В. Б. Антонович найчастіше використовує термін «народ», а не «нація». На нашу думку, переважне послуговування істориком слова «народ» є важливим маркером його поглядів, оскільки останній концепт («нація») передбачає більш високі рівні політичної організованості, самосвідомості етнокультурної спільноти.

Наступне зауваження стосується персоналій. На нашу думку, проукраїнський характер мала діяльність таких викладачів: Харківського університету - Д. І. Багалія та М. Ф. Сумцова, Київського університету св. Володимира - М. П. Драгоманова, В. Б. Антоновича, В. Ю. Данилевича, М. В. Довнар-Запольського, В. М. Перетца, Новоросійського - А. С. Синявського, О. І. Маркевича, О. С. Грушевського; та Ніжинського історико-філологічного інституту імені кн. Безбородька В. Г. Ляскоронського. У той же час в інших вишах Російської імперії працювали відомі пропагандисти української національної ідеї: наприклад, у Московському університеті О. С. Грушевський та Д. І. Яворницький, у Петербурзькому -M. І. Костомаров. До речі, заняття українознавчою тематикою автоматично не означало проукраїнські погляди автора (I. І. Срезневський, Т. Д. Флоринський).

Наступне застереження. Ми далекі від трактовки педагогічної та науково-організаційної роботи, творчості В. Б. Антоновича та інших відомих учених з проукраїнськими переконаннями лише як розробки та поширення української національної ідеї.

Також потрібно враховувати цензуру та авторську самоцензуру, вимушене «подвійне» життя одного 3 лідерів українського національного руху, який зробив типову для держслужбовця кар `єру. Надруковані у часописах Російської імперії й окремими виданнями наукові праці В. Б. Антоновича значно більш помірковані, ніж рукописи чи думки, викладені у неофіційних бесідах чи приватному листуванні. Про відмінність поведінки В. Б. Антоновича у публічному та приватному житті писав у своєму щоденнику близький до нього (до того ж ще і родич) О. Ф. Кістяківський: «Про ідеї Антоновича, дивно, я нічого певного сказати не можу. Тобто я кажу про подробиці ідеї малоросійської. Що вони в голові Антоновича дуже ясні й дуже певні, це безсумнівно. Вони, можливо, ясніші й певніші, ніж ми гадаємо. В усякому разі, ймовірно, вони радикальніші, ніж оця видима оболонка його натури, скромної, далекої від будь-якої різкості» ${ }^{7}$ В його лекціях, які він читав у Київському університеті Св. Володимира та на Вищих жіночих курсах, чітко не прослідковується спроба розглядати українську («південноруську», «малоруську») історію окремо від загальноросійської (східнослов`янської).

Разючу відмінність у публічному та приватному житті В. Б. Антоновича його учень I. А. Линниченко пояснював «страхом репресій, покарань, важких та образливих пояснень, висилки» ${ }^{8}$. В. Б. Антоновича неодноразово допитували у поліції щодо участі у різних радикальних організаціях, знайомств з революціонерами․․ За підрахунками С. І. Світленка в архіві Київського, Подільського і Волинського генерал-губернатора зберігаються 
42 доноси польських поміщиків на В. Б. Антонович, а сам він впродовж першої половини 1860 -х рр. неодноразово допитувався слідчою комісією за 12 політичними справами ${ }^{10}$. Проте на відміну від М. П. Драгоманова, Д. І. Яворницького та ряду інших учених, які за активну участь у національному русі підросійської України також звинувачувались в українофільстві, це не завадило кар'єрі В. Б. Антоновича.

Окрім приміщень Київського університету та Вищих жіночих курсів, спілкування викладачів зі студентами відбувалося і в позаудиторний час. Так, В. Б. Антонович читав приватні («без дозволу начальства») лекції. На думку С. І. Світленка, таких неофіційних лекційних курсів було не менше дев'яти: $з$ антропології, географії, географії України, етнографії України, історії Ірландії, історії козацтва, історії конституціоналізму в Швеції і Норвегії, з філософії та філософії історії ${ }^{11}$. Ці неофіційні лекції читалися українською мовою для 20-30 слухачів здебільшого у будинку самого професора на вул. Жилянській, а також у лікаря Ф. Панченка та адвоката П. Дашкевича, композитора М. В. Лисенка, Є. К. Трегубова, В. Н. Вовка-Карачевського ${ }^{12}$. Як згадував М. С. Кононенко, В. Б. Антонович виступав українською мовою, цілком вільно й легко ${ }^{13}$. На лекції, які відбувалися у професорській квартирі на вул. Жилянській, щосуботи приходив околодочний для отримання 10 крб. Лише за умови отримання «подарунку» поліція не помічала регулярного зібрання молоді у приватному будинку ${ }^{14}$.

Як згадував С. О. Єфремов, майже усі викладачі «просто гребували наукою про рідний край, справляючи ту саму місію, якій все слугувало в централізованій Росії» ${ }^{15}$. Частина вчених не сприймала історію України як історію окремого народу. українська мова розглядалася ними як діалект російської. Тому вважаємо приватні лекції В. Б. Антоновича, які 3 перервами читалися майже чверть століття (інколи до 4-х разів на тиждень ${ }^{16}$ ), його громадським подвигом. Наша оцінка збігається з оцінками інших дослідників. Значення приватних лекцій В. Б. Антоновича С. І. Світленко вбачає у поширенні українознавчих знань: «Під впливом лекцій В. Б. Антоновича серед його слухачів і слухачок виникав інтерес до історії та географії України, до ії долі» ${ }^{17}$. Погоджуємося і $з$ думкою В. Ю. Харченка: «За умов неофіційних читань професор мав змогу вільно висловлювати власні не лише наукові, але й громадські погляди, виховуючи у національному дусі як університетське студентство, так і слухачок Вищих жіночих курсів» ${ }^{18}$.

Неофіційне спілкування В. Б. Антоновича зі студентською молоддю не переривалося під час канікул. Влітку професор супроводжував групи молоді на екскурсії, в тому числі до Львова, «щоб зазнайомитися ближче 3 побутом, національно-культурним розвитком $\mathrm{i}$ політичним життям Галичини» ${ }^{19}$.

Важливим маркером проукраїнськості В. Б. Антоновича було його переконання у необхідності використання української мови у науковому житті. Як член підготовчого комітету XI Археологічного з їзду у Києві (1899р.) він намагався добитися дозволу для науковців 3 Галичини виступати українською мовою 20 . Пізніше учений публічно розкритикував підхід іншого професора Київського університету Т. Д. Флоринського, який заперечував доцільність використання у науці української мови ${ }^{21}$.

У 1905 р. В. Б. Антонович був одним з авторів записки до Міністерства народної освіти з пропозицією скасувати обмеження використання українського слова. Необхідність скасування такого обмеження обгрунтовується таким чином: «Малоросія ввійшла до складу Російської держави добровільно, без завоювань та боротьби і, внаслідок чого, внесла у нову державу лише почуття любові та єднання, без тіні будь-якого роздратування чи озлоблення. Малоруська література ніколи не підіймала навіть натяку про політичний сепаратизм і завжди вважала цей мотив для себе чужим» ${ }^{22}$.

Публічно декларуючи свою лояльність як громадянина Російської імперії до своєї держави, В. Б. Антонович у приватному листуванні припускав можливість об єднання усіх українських земель на федеративних засадах у складі іншої держави. Так, у листі до М. П. Драгоманова він писав: «Безперечно, укр[аїнст]во неможливе без федеративно-автономічних прагнень, але що, прикладаючи всі реальні на сьогодні шанси, я і більшість моїх знайомих маємо більше надії на здійснення федералізму південно-західно-слов янського, ніж російського, та що таку форму вважали б за бажанішу»²3.

У середовищі науковців 3 українофільськими поглядами того часу переважала думка про те, що інтереси народів можуть бути краще враховані у федерації. На переконання 
В. Б. Антоновича, у ряді сучасних йому європейських держав державні установи можуть гарантувати «і матеріальну безпеку суспільства та благоустрій, і задоволення ними вищих моральних потреб: свободу совісті, можливість розумового розвитку тощо» ${ }^{24}$. Тому, на його думку, недержавні нації «можуть не лише жити спільно в єдиній державі, але й у рівній мірі дорожити іiі міцністю, іiі законами та установами, якщо ці установи гарантують їх загальні права і рівно всім надають покровительство і захист» ${ }^{25}$. Тож він високо оцінював ліберальні реформи в Австро-Угорській імперії, вважаючи, що облаштована державна система за західним взірцем має багато переваг і позитивно впливає на внутрішнє життя Галичини ${ }^{26}$. У той же час учений вважав населення Західної України неготовим до реформ в АвстроУгорщині: «Якщо у відомій країні немає громадської підготовки, а закони ій надаються ліберальні, то результатів або зовсім не отримують, або одержують дуже шкідливі $\rangle^{27}$.

В. Б. Антонович вважав становище українців у Російській імперії гіршим, ніж в Австро-Угорщині. Учений вкрай негативно оцінював урядову русифікацію, вважаючи ії головною перешкодою розвитку української культури, науки та освіти. Тому професор вважав шкідливим вплив імперської російської культури на українців і закликав більше орієнтуватися на західноєвропейські цінності: «Коли українці будуть засвоювати загальнолюдські ідеї й вищу культуру з творів західноєвропейської думки чужоземними, більш далекими мовами, то вони не будуть так втрачати свою рідну мову, як тепер; вони будуть намагатись висловлювати ці ідеї своєю мовою і цим сприятимуть ії розвитку, а разом з тим і розвиткові рідної літератури й культури. Нехай молодь вчиться чужоземних мов, читає багатшу на ідеї західноєвропейську літературу - це буде корисніше для неї, ніж вплив російської літератури» ${ }^{28}$.

В той же час В. Б. Антонович вірив, що і в підросійській Україні у майбутньому завдяки демократичним реформам та широкій культурно-просвітницькій роботі серед населення будуть створені кращі умови розвитку української свідомості, культури, науки та освіти. У приватних лекціях про козацтво історик, наприклад, стверджував: «Без жодного сумніву, у нас здобуття національних прав пізніше трапиться, але в міру того, як національна свідомість буде ширитися в маси, і тут будуть забезпечені народові права культурно-національного життя» ${ }^{29}$.

В. Б. Антонович 3 точки зору інтересів суспільства вважав кращим шлях реформ та культурно-просвітницької роботи, ніж революційну боротьбу. В той же час, як згадує М. В. Беренштам-Кістяківська, учений у відповідь на питання слухачок ВЖК (18861887 навч. р.) як діяти більш рішуче для допомоги простому народу допускав можливість революції. Він попередив молодь про небажаність штучного створення революційних ситуацій: «Народні рухи на загад не робляться, нарід можна тільки готувати до них, а як обставини наспіють, то й найменшої зачіпки досить буде, щоб зайнялася революція» ${ }^{30}$.

Молодий В. Б. Антонович надрукував «Мою сповідь», в якій запропонував польським шляхтичам підросійської України обирати два шляхи: «Полюбити народ, серед якого вони живуть, проникнутися його інтересами... і невтомною працею та любов'ю по мірі сил віддячити все зло, що причинене ними народу» або «переселитися до землі польської» ${ }^{31}$. Він вважав реальні справи кращою допомогою інтелігенції простому народу: «Справжні друзі народу не ламають собі голову над далеким майбутнім, але якщо вони люди справи і якщо мають кошти, то дбають про народну просвіту, про покращення матеріального побуту селян $\rangle^{32}$.

У заяві 1862 року, складеній М. П. Драгомановим за безпосередньої участі В. Б. Антоновича і підписаній ними та ще 20-ма київським громадівцями (серед них П. П. Чубинський, П. Г. Житецький, Т. Р. Рильський, Б. С. Познанський), культурно-просвітницька робота для простого народу проголошувалася «єдиним обов'язком людей, що встигли отримати вищу освіту» ${ }^{33}$. Культурництво, на їх переконання, мусило бути насамперед практичним і полягати в тому, щоб «використати усякі зусилля з метою надати народу можливість становитися освіченим, усвідомити себе, свої потреби, вміння заявити їх... Поки... марно буде придумувати для нього, та до того ж і без нього, подальші шляхи прогресу; усяка теорія від парламентської англійської системи до найяскравіших соціалістичних тлумачень, за нашим переконанням, лише химерна мрія...; поки народ неясно усвідомлює теперішні свої потреби або навіть не усвідомлює їх, який сенс у тій чи іншій теорії, та до того ж узятої не $з$ народного життя, не за складом народної логіки?» ${ }^{34}$. 
Ідею служіння простому народу В. Б. Антонович активно пропагував серед молоді. Історик, за свідченням В. Г. Ляскоронського, у спілкуванні зі студентами «нагадував своїм слухачам принципи морального обов язку до рідного краю, що про його добро повинен дбати і працювати для нього кожний його вдячний син» ${ }^{35}$.

Поширенню української ідеї також сприяли й наукові доповіді В. Б. Антоновича та друк українознавчих публікацій у часописах та виданнях наукових товариств. Наприклад, В. Б. Антонович у 1881 р. виступив 3 доповіддю про Т. Г. Шевченка в Історичному товаристві Нестора-літописця. Він відмітив, що, попри маленькі фактичні помилки, поет досить правильно розуміє та відтворює історичне минуле, зокрема Запоріжжя. В. Б. Антонович вважав, що «не можна ототожнювати поета з істориком; поет - художник і не його справа шляхом критики та тривалої кропіткої праці відновлювати окремі факти минулого життя та потім узагальнювати ці факти історико-філософською синтезою...Поет відтворює живий та цілісний образ епохи... для митця не має значення фактична точність подробиць, лише б вони були можливі на фоні епохи, що ним зображується» ${ }^{36}$.

Розповсюдженню національної ідеї сприяла і діяльність під керівництвом В. Б. Антоновичем двох гуртків, які займалися складанням словника української мови та пізніше історико-географічного словника українських земель ${ }^{37}$.

Важливу роль у формуванні української національної ідеї мали наукові праці В. Б. Антонович. Порівнюючи українців з росіянами та поляками у статті «Три національні типи народні ${ }^{38}$ історик пише про бездержавність українців. В іншій праці він також наголошував, що українська народність «абсолютно позбавлена державного інстинкту, вона не лише не створила окремої держави, але і добровільно відклала утворення такої навіть в той час, коли історичні обставини давали для цього можливість (в половині XVII ст.)») Учений у розвідці про Б. Хмельницького підкреслював, що український народ «завжди готовий був приєднатися до готової держави, щиро підкоритися його владі, підтримувати та дорожити ії̈ авторитетом $\gg^{40}$. Тому, за його оцінкою, українцям достатньо національнокультурної автономії в складі іншої держави. Такий підхід В. Б. Антонович обгрунтовував тим, що «бездержавні нації у великій більшості випадків не мріють про утворення окремих держав, але цінують збереження свого природного національного типу й мають право розраховувати на те, що держава, до складу якої вони входять, на користь якої несуть державні повинності, з якою вони поділяють історичну долю та громадський побут, дасть їм можливість зберегти свій тип і розвивати його шляхом культури» ${ }^{41}$. Лідер Старої Київської громади активно виступав за забезпечення «народові права культурно-національного життя $\rangle^{42}$.

В. Б. Антонович пов'язував благополучне життя простого народу не стільки з правильною роботою органів влади, скільки із загальною ліквідацією економічної та культурної відсталості народних мас. «Громадське самоуправління, - вважав історик, - це постійна мета, до якої прагнув український народ» ${ }^{43}$. Учений 3 типово просвітницьких позицій надзвичайно високо оцінював значення загального рівня культури для суспільного розвитку нації: «Що би принцип демократизму набрався переважної сили і значення, треба, щоб громадська маса досягла високого ступеня культурного розвитку та щиро переконалася у правдивості ідеї... При низькому ступені культури, коли над громадськими інтересами панує переважно особиста вигода окремих людей та станів, демократія не має способу розвинутись та взяти гору» ${ }^{44}$. На підтвердження цієї тези В. Б. Антонович наводить приклад Хмельниччини, «коли історичні обставини сприяли найліпше, одначе ж увести в життя провідну ідею українського народу не довелося, бо на те не стало культурного розвитку, переконань та витривалості» ${ }^{45}$. Вчений вважав, що український народ «ніколи не міг виробити ані грунтовної цивілізації, ані міцної власної дисципліни; бо ті, що ставали на чолі його, бралися піклуватись народною долею, мали у собі вельми недостатній запас культури ${ }^{46}$. Науковець називав дієвим засобом покращення життя народу різні форми та напрями культурно-просвітницької роботи серед населення. На його думку, «чим більше вноситься до нього [народного самопізнання - О.Б.] ... правди та науки, тим вище, моральніше, а відповідно, й могутніше стає даний народ» ${ }^{47}$.

Держава та народ визнавалися науковцями того часу основними суб'єктами історичного процесу. В. Б. Антонович дав визначення народу як «сукупності антропологічних, етнографічних та духовних ознак, якими відрізняється одна група людства від іншої; озна- 
ки ці вироблялися самою природою під впливом досить складних природних факторів: змішування рас, клімату, заняття, пережитої історичної долі тощо; як все, що створене природою, ознаки ці відрізняються великою тривалістю» ${ }^{48}$. Для характеристики народу учений в іншій праці («Погляди українофілів») до антропологічних, психологічних, культурно-історичних ознак додає лінгвістичні ${ }^{49}$. У статті «Три національні типи народні» В. Б. Антонович називає мову головною ознакою нації і одночасно, як приклад, навів виняток - ірландський народ, котрий втратив власну мову ${ }^{50}$.

Крім того, В. Б. Антонович виділяв два типи особливостей («прикмет»), що відрізняють один народ від іншого: «природжені людям, спадкові» та ті, що «здобуваються вихованням» ${ }^{51}$.

У розмовах із В. М. Щербаківським В. Б. Антонович, який вже на той час викладав приватним чином лекції з антропології, детально охарактеризував антропологічні (особливості скелету та черепу, жирової тканини) і психологічні (різниця темпераменту та реактивності) відмінності поляків, росіян, українців. На переконання В. Б. Антоновича, моральна діяльність людини складається з трьох елементів: 1) атавізм, «дідизна», отримана від предків - 75\%; 2) виховання - 5-10\%; 3) власна ініціатива - до $15 \%{ }^{52}$. Він пояснював запізнілий характер стихійних виступів українців проти несправедливості саме особливою реакцією на образи: «Українець на образу зразу ж не відповість, а через се сама образа страшенно його мучить..., і потім мала іскра, навіть не образа викличе страшну відповідь за всі випадки заразом і зовсім невідповідно силі останньої образи» ${ }^{53}$. Вчений неодноразово у розмовах підкреслював необхідність знайти «деякі постійні відношення або особливості» кожного народу, бо був переконаний, що «характер народу... не залежить від часу і знаходиться в певнім відношенню до розвою історії, до історичних подій ${ }^{54}$. В. Б. Антонович наголошував більше на психолого-культурологічних, а не політико-державницьких чи інших ознаках нації: «Нація - це група людей рідних і близьких між собою натурою, хистом, вдачею, дотепом, вдатністю, темпераментом» ${ }^{55}$. «Кожний нарід, - вважав лідер вітчизняної народницької історіографії, - у своєму політичному житті має властиву йому провідну ідею, а вона залежить почасти від антропологічних расових причин, почасти від різних условин та впливу територіальних обставин, від історичного життя, від культурного розвитку і т. ін.» ${ }^{56}$. Вчений виділив головні принципи життя трьох народів: російський - «абсолютизм», «принцип авторитету державної влади»; польський - принцип демократичної аристократії; український - «принцип вічевий, принцип широкого демократизму [курсив автора - О.Б.] і признання рівності політичного права задля кожної одиниці суспільства» ${ }^{57}$. Саме високою громадською самоорганізацією українців дослідник пояснював небажання українського народу створювати окрему державу.

В. Б. Антонович виділяв такі фактори ідентифікації українського народу: «географічний», бо «навіть якщо припустити повне зникнення сучасного південно-руського народу та колонізацію зайнятої ним території великоросами, то під впливом географічних та кліматичних умов через декілька століть великороси, що оселилися на півдні, утворили б відмінну від сородичів, що залишилися на півночі, етнографічну спільноту, подібно до того, як південнороси, що переселилися на північ у X-XII століттях, виділися в тип сучасного великороса» та «антропологічний» (великий вплив тюрків на формування антропологічних ознак українців подібно до впливу фінських племен на росіян) ${ }^{58}$. На переконання В. Б. Антоновича, «народний характер» українців заважає їм створити власну державу: «Південно-руський народ внаслідок особливостей етнографічного складу свого народного характеру не володів здатністю створити незалежну державу» ${ }^{59}$. I в іншому місці цієї праці: «Народ повинен володіти значною частиною самовладання, вміти утримуватися кожної даної хвилини від дій, що викликані впливом безпосередніх вражень, через майбутні спільні вигоди; повинен вміти жертвувати частиною, іноді доволі значною, особистої волі та особистих побажань на користь влади, яка покликана до організації суспільства та керівництва державними цілями. Ці якості південно-руський народ ніколи не мав і сам глибоко усвідомлював їх відсутність» ${ }^{60}$. Щоправда усі ці характеристики київського професора стосувалися здебільшого українців, що мешкали на терені Російської імперії.

Отже, одним з ідеологів та пропагандистів української національної ідеї був науковець та громадський діяч В. Б. Антонович. Широка трактовка «українофільства», т. зв. 
українського питання В. Б. Антоновичем засвідчує, що київський вчений (на відміну від того ж М. І. Костомарова) фактично еволюціонує від оцінки українства як малоросійської (амбівалентної) ідентичності до розуміння національної ідентичності як суто української. У складних суспільно-політичних умовах урядових гонінь на українство професор зумів знайти канали поширення української ідеї, яка лише формувалася у XIX ст. Частина іiі розробників, в тому числі В. Б. Антонович, не пропонували створення окремої української держави. У розумінні науковця нездатність українського народу до державотворення $\epsilon$ специфічною рисою українців, яким краще жити у федерації з більш сильною державною (титульною) нацією. Неоціненна роль В. Б. Антоновича у сприйнятті його студентами ідей українофільства під час навчального процесу та позаудиторного спілкування, у різних формах науково-організаційної та громадської роботи. Учений запропонував нові підходи до вивчення націй. Відносячи українців до бездержавних націй, В. Б. Антонович у своїй громадській, науково-організаційній, культурно-просвітницькій діяльності прагнув компромісу з самодержавством. В. Б. Антонович продовжив легітимацію національної історії, в тому числі захист прав народу на певну територію, питання давності походження та самого існування етносу, окремішність українців від росіян і поляків в історії, культурі та мові тощо.

${ }^{1}$ Сфремов С. О. Вибране: статті, наукові розвідки, монографії. К., 2002. С. 705.

${ }^{2}$ Сфремов С. О. Вибране: статті, наукові розвідки, монографії. С. 34.

3 Франко I. 60-ті роки на Україні // Син України: Володимир Боніфатійович Антонович: у 3 т. К., 1997. Т. 1. С. 28.

${ }^{4}$ Синявський А. С. Вибрані праці. К.: Основи, 1993. С. 42.

${ }^{5}$ Антонович В. Б. Моя сповідь. Вибрані історичні та публіцистичні твори. К., 1995. С. 144.

${ }^{6}$ Костомаров Н. Украинофильство // Русская старина. 1881. Т. 30, кн. 2. С. 319.

${ }^{7}$ Кістяківський О. Ф. Щоденник: 1874-1885: У 2 т. К.: Наукова думка, 1995. Т. 2 (1880-1885). C. 74 .

8 Линниченко И. Владимир Бонифатьевич Антонович. 1830-1908 // Син України: Володимир Боніфатійович Антонович. К., 1997. Т. 1. С. 348.

${ }_{9}^{9}$ Центральний державний історичний архів України, м. Київ. Ф. 473. Оп. 1. Спр. 20. Арк. 98, 210 $215,417,485,503,536-542$ та ін.

${ }^{10}$ Світленко C. I. Українські інтелектуальні зв'язки професора В. Б. Антоновича // Наддніпрянська Україна: історичні процеси, події, постаті. 2012. Вип. 10. С. 130.

11 Там само. С. 135.

12 Там само. С. 133-134; Беренштам-Кістяківська М. Українські гуртки в Києві другої половини 1880-их та початку 1890-их років // За сто літ: Матеріяли $з$ громадського й літературного життя України XIX і початків XX століття. К., 1928. Кн. 3. С. 207.

${ }^{13}$ Кононенко М. Спогади. Полтава: Полтава, 1998. С. 172-174.

${ }_{14}^{14}$ Там само. С. 173.

15 Єфремов С. Українознавство : покажчик потрібнішої для самоосвіти літератури. К.: Друк. Всеукр. кооп. видавнич. союзу, 1920. С. 4.

16 Данилевич В. В. Б. Антонович как профессор // Син України: Володимир Боніфатійович Антонович. К., 1997. Т. 1. С. 388.

${ }_{17}^{17}$ Світленко C. I. Українські інтелектуальні зв’язки професора В. Б. Антоновича. С. 135.

${ }^{18}$ Харченко В. Володимир Антонович у 1864-1884 рр.: трансформація ідейно-тактичних засад i початки політики // Просемінарій. Медієвістика. Історія церкви, науки і культури. К., 2000. Вип. 4. C. 204.

${ }_{19}^{19}$ Беренштам-Кістяківська М. Українські гуртки в Києві другої половини 1880-их та початку 1890-их років. С. 207.

${ }^{20}$ Гирич I. М. Грушевський та В. Антонович: творчі контакти та суспільно-політичні погляди // Академія пам'яті професора Володимира Антоновича. К., 1994. С. 140-141.

${ }^{21}$ Антонович В. Б. К вопросу о галицко-русской литературе (По поводу статьи проф. Т. Д. Флоринского) // Киевская старина. 1900. Кн. 3. С. 306-423.

22 Антонович B. Записка Вол. Антоновича в справі обмежень української мови // Записки Українського наукового товариства в Києві. 1908. Кн. 3. С. 38-39.

${ }^{23}$ Цит. за: Харченко В. Володимир Антонович у 1864-1884 рр.: трансформація ідейно-тактичних засад і початки політики. С. 209.

${ }^{24}$ Антонович В. Польско-русские соотношения XVII в. в современной польской призме (по поводу повести Г. Сенкевича “Огнем и мечём”) // Киевская старина. 1885. Кн. 5. С. 48-49. 
${ }^{25}$ Антонович В. Б. Погляди українофілів // Моя сповідь: вибр. іст. та публіцист. Твори / В. Б. Антонович. К., 1995. С. 151.

${ }^{26}$ Інститут рукопису Національної бібліотеки ім. В. І. Вернадського Національної академії наук України (далі - ІР НБУВ). Ф. 1. Од. збер. 8083. Арк. 3-6.

${ }^{27}$ ІР НБУВ. Ф. 1. Од. збер. 8093. Арк. 145.

${ }^{28}$ Сгунова-Щербина С. Пам’яті В. Б. Антоновича (сторінка споминів) // Син України: Володимир Боніфатійович Антонович. К., 1997. Т. 1. С. 376.

${ }_{29}$ Антонович В. Б. Про козацькі часи на Україні. К. : Дніпро, 1991. С. 211.

${ }^{30}$ Беренштам-Кістяківська М. Українські гуртки в Києві другої половини 1880-их та початку 1890-их років. С. 209.

31 Антонович B. Моя исповедь. Ответ пану Падалице по поводу статьи в VII книжке “Основы” “Что об этом думать” и письма г. Падалицы в Х книжке // Основа. 1862. № 1. С. 94.

${ }^{32}$ Там само. С. 88

${ }_{33}$ Матеріали для біографії В. Б. Антоновича. 3 приводу двадцятої річниці з дня його смерті / за ред. Д. І. Багалія. К. : Друк. ВУАН, 1929. С. 39-40. C. 40 .

34 Матеріали для біографії В. Б. Антоновича. 3 приводу двадцятої річниці з дня його смерті.

${ }^{35}$ [Ляскоронський В. Г.]. Невидані спогади В. Г. Ляскоронського за Володимира Боніфатієвича Антоновича як професора // Син України: Володимир Боніфатійович Антонович. К., 1997. Т. 1. C. 397.

${ }^{36}$ Антонович В. Б. Произведения Шевченко, содержание которых составляет исторические события // Твори. К., 1932. Т. 1. С. 154.

${ }^{37}$ Кістяківський О. Ф. Щоденник: 1874-1885: У 2 т. К.: Наукова думка, 1995. Т. 2 (1880-1885). C. 416 .

${ }^{38}$ Антонович В. Б. Три національні типи народні / В. Б. Антонович // Моя сповідь : вибр. іст. та публіцист. твори / В. Б. Антонович. К., 1995. С. 90-101.

${ }^{39}$ Антонович B. Записка Вол. Антоновича в справі обмежень української мови // Записки Українського наукового товариства в Києві. 1908. Кн. 3. С. 38.

${ }^{40}$ Антонович B. Характеристика деятельности Богдана Хмельницкого // Чтения в Историческом обществе Нестора-летописца. 1899. Кн. 13. С. 102.

${ }^{41}$ Антонович B. Записка Вол. Антоновича в справі обмежень української мови. С. 38.

${ }^{42}$ Антонович В. Б. Про козацькі часи на Україні. С. 211.

${ }^{43}$ Антонович $B$. Моя исповедь. Ответ пану Падалице по поводу статьи в VII книжке “Основы” “Что об этом думать” и письма г. Падалицы в Х книжке. С. 88.

${ }^{44}$ Антонович В. Б. Про козацькі часи на Україні. С. 19-20.

45 Там само. С. 20.

${ }^{46}$ Там само. С. 21.

${ }^{47}$ Антонович В. Н. И. Костомаров как историк // Киевская старина. 1885. Кн. 5. С. XXXIII.

${ }^{48}$ Антонович B. Записка Вол. Антоновича в справі обмежень української мови. С. 37.

49 Антонович В. Б. Погляди українофілів. С. 144.

50 Антонович В. Б. Три національні типи народні // Моя сповідь : вибр. іст. та публіцист. твори / В. Б. Антонович. К., 1995. С. 90.

${ }^{51}$ Антонович В. Б. Три національні типи народні. С. 90.

${ }^{52}$ Антонович В. Б. Автобіографічні записки Володимира Антоновича // Літературно-науковий вістник. 1908. Т. 43, кн. 7. С. 3-4.

${ }^{53}$ Національний архів Чехії. F. 904. К. 77; опубл.: Щербаківський В. Спогади про В. Б. Антоновича // Пам’ятки України. 2007. № 4. С. 209.

54 Там само. 209.

${ }_{55}$ Антонович В. Б. Три національні типи народні // Моя сповідь : вибр. іст. та публіцист. твори / В. Б. Антонович. К., 1995. С. 91.

${ }_{56}$ Антонович В. Б. Про козацькі часи на Україні. С. 17.

57 Антонович В. Б. Про козацькі часи на Україні. С. 18-19.

${ }_{58}$ Антонович В. Б. Погляди українофілів. С. 145.

59 Антонович В. Характеристика деятельности Богдана Хмельницкого // Чтения в Историческом обществе Нестора-летописца. 1899. Кн. 13. С. 102; подібна думка: Антонович В. Б. Погляди українофілів. С. 149.

${ }^{60}$ Антонович В. Характеристика деятельности Богдана Хмельницкого. С. 102. 